Among miscellaneous grants, the report refers to one of $£ 9,000$ to the Imperial Agricultural Bureau to accommodate the Empire potato collection, and one of $£ 1,500$ to the Medical Research Society to permit purchase of the assets of the journal Clinical Science and to prevent a rise in price of the journal during the next five years.

$$
\text { III: }
$$

\section{UNITED STATES NATIONAL} MUSEUM

\section{REPORTISTR 1944 AND 1945}

$\mathrm{T}$ HE exten work carried out by the United Stateg National Museum in the interest of the war effard an outstanding feature of the report for 1944 (W. Shington, D.C. : Gov. Printing Office, 35 cents). U uder the heading, "The Museum in Wartim Me chief of the departmental services rendered are described. Some of these include the following : Dr. Kellogg's preparation (for the National Research Council) of text and illustrative matter relative to monkeys known to be susceptible to infection by malarial parasites; the supply to various organisations of the Services of information regarding the identification and distribution of mammals involved in the transmission of diseases; the provision of information relating to the habits of certain mosquitoes, mites and ectoparasites sent in for identification by various Army and Navy units; the supply (to Army and Navy medical and other training centres throughout the country) of several hundreds of specially mounted specimens of insects and Acarina species involved in human health problems; suggestions for tropical and Arctic clothing; information regarding water supply and population statistics of the Caribbean Islands, house types in Burma, and the degree of western influence in certain Pacific islands and in the Philippines; the provision of information (based on collections in the Department of Anthropology) regarding the resources of certain strategic areas, and so on.

During 1944, Dr. G. A. Cooper concluded his field studies on the stratified rocks of Sonora, and it is reported that the results of his work (to be published shortly) will assist in the location of new mineral areas. Dr. Cooper also finished field-work on a project concerned with the Devonian sub-surface geology of Illinois, and information has been obtained which will be useful for the oil development of that and neighbouring States. Other work connected with the Department of Geology included the continued supervision by W. F. Foshag of surveys for strategic minerals in Mexico.

Under the section of the report dealing specifically with the activities of the Department of Geology, reference is made to the present-day scientific value of plaster casts of type fossils-"in view of the destruction taking place in foreign museums". In this connexion, mention is made of a cast of the English Carboniferous crinoid, Poteriocrinites crassus Miller, received as a gift from the British Museum (Natural History). The holotype and only specimen of this was housed in the Bristol Museum, which was destroyed by enemy action during the War.

The report ends with a 28-page list of accessions, and a list of the Museum's publications issued during the fiscal year 1943-44.
The report for 1945 of the United States National Museum (25 cents) comments on the necessity for additional housing space if the progressive work of the Museum is not to be hindered. In this connexion, allusion is made to the wealth and utility of the Museum's scientific materials in the future development of American natural resources, agriculture and industry. Congress has already authorized the addition of wings to either end of the Natural History Building as soon as public building projects are possible, and now plans for separate buildings for engineering and industries and for American history have been estimated for authorization. The proposed engineering and industries building would take the place of the present arts and industries building, which is, to quote the report, "an antiquated brick structure ... no longer suitable for modern installations in museum display".

\section{ifl: \\ JOHN INNES HORTICULTURAL INSTITUTION}

\section{ANNUAL. REPORT}

$T$ HOSE whMre acquainted with the limitations of space Ader which the John Innes Horticultural If ifitution has laboured in past years will welcome the forthcoming transfer to its new site at Bayford Pury Park, Hertfordshire, already described in Nature $(156,586 ; 1945)$.

Tip thirty-sixth annual report of the Institution, for $\mathbf{4 5}$, covers a very wide field of investigation.

The replacement of existing virus-infected, lowyielding clonal stocks of raspberries is a pressing necessity. M. B. Crane's work on high-yielding $F_{1}$ families of seedling raspberries promises to provide a rapid method of producing virus-free seedling stock of sufficient uniformity. He records that the yield of the best hybrid family is 60 per cent higher than that of a selected stock of Norfolk Giant. Further extensive trials of $F_{2}$ families planted in 1945 have been bred for greater uniformity, especially in respect to firmness and colour of fruit:

Several investigations on the tomato are in progress ; A. G. Brown, working on hybrid vigour, reports in all cases considerably higher yields from $F_{1}$ families than from either parent. A breeding investigation aimed at combining high yield with early maturity is in progress. Dr. D. Lewis is endeavouring to obtain a degree of frost hardiness in hybrids derived from crosses between certain wild species of tomato, collected from high altitudes in Peru, and cultivated varieties. Messrs. W. J. C. Lawrence and J. Newall have shown, notably in tomatoes, that earliness and total yield depend to a remarkable degree on seedling treatment designed to avoid any check to rapid development. Factors of great importance are the minimizing of root disturbance by pricking out small seedlings directly into pots, and the employment of pots sufficiently large to allow unrestricted root development. Further experiments show the importance of adjusting the fertilizer balance and concentration in the seedling compost to an optimum level, and the feeding of root-bound plants with a balanced fertilizer prior to transplanting. In winter, however, the influence of reduced light intensity in glasshouses is shown to be of over-riding importance, outweighing all other factors. 